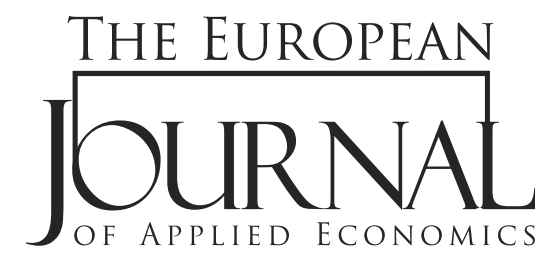

\title{
THE IMPACT OF THE BUSINESS SECTOR ON CHILDREN'S RIGHTS IN SERBIA
}

\author{
Nataša Krstić*, Sandra Nešić \\ Faculty of Media and Communications, \\ Singidunum University, \\ Belgrade, Serbia
}

\begin{abstract}
:
The business sector has a strong direct and indirect impact on children, at the workplace, on the marketplace, in the community, and through the supply chain, where risks arise in terms of endangering children and their rights. This paper aims to provide new evidence of the impact of the business sector on children's rights in Serbia. The analysis of the impact of the Serbian business sector on children's rights was carried out through cabinet research of three sectors identified as a priority based on their influence on the economy and children's rights - ICT, food and agriculture, and financial sector. After interviews with managers responsible for corporate social responsibility in the leading companies from these sectors, their potential impact on children's rights has been mapped together with sectoral risks, while opportunities for shared-value engagement between businesses and organizations and institutions supporting children and their rights were extracted. Our research suggests that shared value in the context of the promotion of children's rights goes far beyond traditional corporate philanthropy, and audits how core business operations, assets and practices, advocacy initiatives, skills, and know-how can support children's rights in achieving Sustainable Development Goals.
\end{abstract}

\section{Article info:}

Received: July 11, 2019

Correction: December 2, 2019

Accepted: December 4, 2019

\section{Keywords:}

business principles and children's rights, corporate social responsibility, shared value, Serbia.

\section{INTRODUCTION}

Human rights are relevant to the economic, social, and environmental aspects of corporate activity (Sinha, 2013). On the other hand, corporations impact human rights in significant ways, especially since economic and political influence has grown over decades (Paine and Srinivasan, 2019). Legal and economic research has examined the protection and promotion of human rights in the context of business operations in growing numbers over the last decade (Office of the High Commission for Human Rights, 2011; Remmert, Koalick and Mahler, 2013; CSR Europe, 2016). 
The research has focused on Corporate Social Responsibility (CSR) and its effectiveness; international soft-law mechanisms, such as the United Nations Global Compact (UNGC), and the ethical and moral argumentation of profit-driven companies being assigned social obligations.

Although human rights protection is nowadays an integral part of CSR activities (Obara and Peattie, 2019), children's rights protection is often neglected. CSR has become an essential component of today's business strategy for most companies (Lahtinen, Kuusela and Yrjölä, 2018), while the business sector's impact on children's rights is still relatively unclear, ungoverned and unresearched, especially in Serbia (Krstić, 2018). When assessing the role and the impact of the business sector on children's rights, academic research is predominantly focused on topics such as child labour and exploitation, gender inequality, and ethics of advertising toward children (Carlson and Clarke, 2014). The research by authors Crane and Kazmi (2010) offers broader guidance in implementing CSR activities for children that go beyond moral and physical protection, and address economic welfare, parents' employment conditions, quality of family life, involvement in initiatives that support education and culture, and engagement into partnership for change.

Children are among the most sensitive and vulnerable societal groups, affected both directly and indirectly by the business sector (Berlan, 2016), at the same time being unable to access the mechanisms to participate in making business decisions, and having difficulties in achieving remuneration if their rights were violated (Gerber, Kyriakakis and O'Byrnet, 2013). There is a fine line between respecting children's rights, attracting them as potential consumers, and the point of view where investing in a children-related project is a public relations activity (Berlan, 2016). It is expected from the business sector to take responsibility for its potential impact on children's welfare, instead of developing relationships that are just contributing to brand reputation (Smaiziene, 2015).

Globally, corporate responsibilities extend to ensure that children's rights, from the right to education and health to the right to be free from child labour and discrimination, are respected at each stage of the company's value chain (Collins, 2014).

Nowadays, this is governed under two sets of principles - The United Nations (UN) Guiding Principles on Business and Human Rights, which recommends the steps companies should take to respect human, and especially children's rights, and the Children's Rights and Business Principles (CRBP), built on the Guiding Principles, and which provide guidance that companies can follow to respect and support children's rights in the workplace, marketplace, and community (OHCHR, 2011; UNICEF, UNGC and Save the Children, 2013). In addition, the Children's Rights in Impact Assessments (UNICEF, Danish Institute for Human Rights, 2013) provides useful guidance for companies aiming to integrate children's rights into their formal risk assessment.

Furthermore, as the concept of CSR has evolved, the impact of the business sector on children's rights becomes the focus on exploring and defining opportunities and mechanisms on how to create value for involved stakeholders (Filho, Idowu and Louche, 2010). In that respect, shared value (SV) refers to the approach businesses are taking to create social impact while also enhancing their long-term business value, thus being much broader than CSR (Porter and Kramer, 2011). Until recently, corporate engagement in society has been viewed as a business cost to be traded off against profitability. Traditional approaches to corporate engagement, such as financial contribution and corporate philanthropy, represent a missed opportunity. From a social perspective, they create little incremental value beyond the cash amount donated, and the benefits are mainly in terms of reputation. Increasingly, companies are realizing that, by creating SV, they can benefit society and boost their competitiveness at the same time (Porter and Kramer, 2011). Shared value partnerships (SVPs) between businesses and organizations and institutions supporting children's rights can be found in advocacy initiatives, business practices, core business operations, and assets and with various models of financing (Figure 1). 


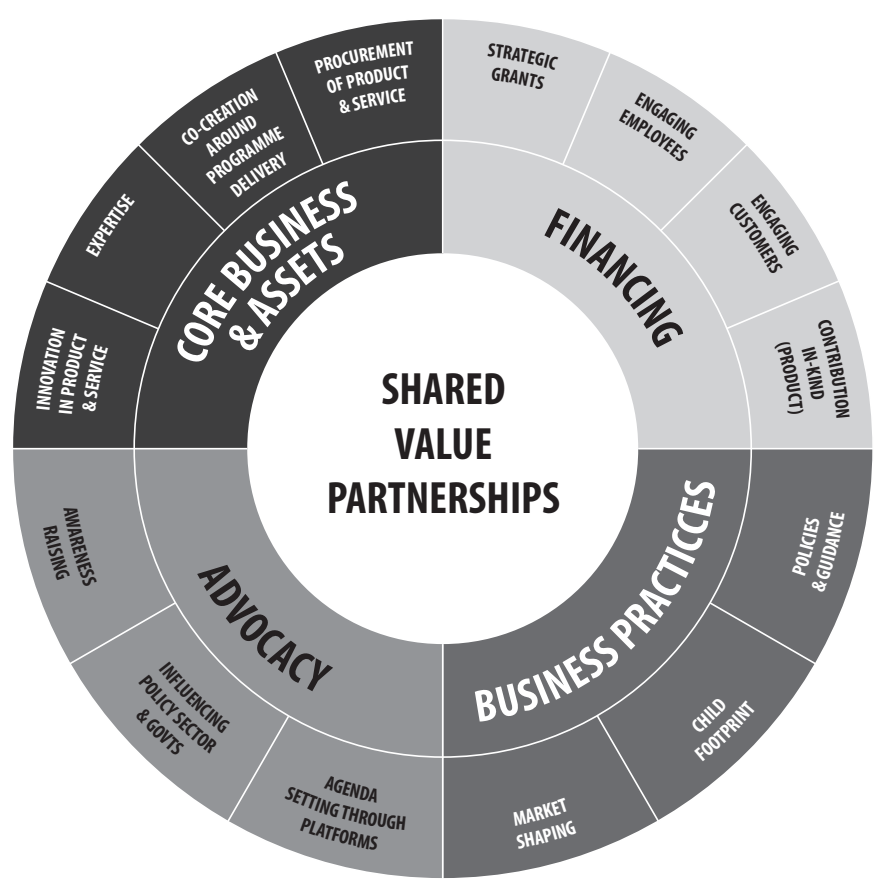

In Serbia, children represent close to one-fifth of the total population (UNICEF, 2016) with high risk-of-poverty rate. Those most exposed to the poverty risk in Serbia are individuals up to 18 years of age, with as much as $30.5 \%$ affected (Statistical Office of the Republic of Serbia - SORS, 2018). The Republic of Serbia has ratified all key international treaties concerning the protection of children's rights, including the Convention on the Rights of the Child - CRC (2001) and two optional protocols. Based on that, the Constitution of the Republic of Serbia guarantees the enjoyment of human rights by children in line with their age and mental maturity, while leaving the detailed regulation of children's rights to laws. The Deputy Ombudsman for Children's Rights and Gender Equality is tasked with monitoring the application of the CRC with the Office of the Ombudsman of the Republic of Serbia. Over the past decade, many laws affecting children's rights have been enacted or amended, and a range of strategic documents in this area have been adopted. Moreover, Chapters 23 and 24 of the European Union (EU) Accession Negotiation Positions and their accompanying action plans are directly related to child rights, while several other chapters may benefit from an increased child-rights focus. The National Plan of Action for Children (NPA), a government strategic document that was to operationalise the commitments that transpired from the CRC and Millennium Development Goals (MDGs) was adopted in 2005, expired in 2015 and has not been revised. The Council for the Rights of the Child as the advisory body of the Serbian Government has been active since 2018, which is expected to be proactive on topics and legislative initiatives supporting children and their rights.

The research aimed at understanding the awareness and implementation of CRBP in Serbia conducted by UNICEF (2018e) concluded that the business sector highly values activities toward children, and frequently engages in them by supporting the areas of education, social protection and childcare services, in promoting healthy lifestyles, and improving living conditions in the community. UNICEF research confirmed that many businesses are interested in supporting child rights within their sustainability strategies, which are however often not explicitly incorporated into their reporting principles, internal strategies and policies. To foster this integration, a sectoral approach towards CRBP should be established. 
Our research aims to assess the potential business impact of top priority sectors, identified based on their influence on the economy and children's rights, perceived risks and opportunities for SV engagement in partnerships with organisations and institutions that support children and their rights. The paper is structured as follows: The first, the introduction section, discusses the theoretical insights on the topics of children's rights as integral part of the universal human rights, CSR and their intersection. The second part of the paper focuses on presenting research methods. Finally, research results are presented and discussed in the third part of the paper.

\section{METHODOLOGY}

For the purpose of this article, a combination of empirical and qualitative research was deployed. In the first phase, several business sectors in Serbia were empirically analysed, which UNICEF globally selected in view of their direct intersection with children's rights (e.g. impact of business operations, products, services on children) and/or potential to amplify the reach through core assets (UNICEF, 2018a). According to the UNICEF methodology, the following sectors were selected: Information and Communication Technology (ICT), Food and Agriculture, Pharmaceutical and Healthcare Equipment, Tourism, Textile, Retail Trade, Media, Sports and Toys, and Banking and Insurance. In that respect, the term 'sector' is used to address a collection of industries under a shared area of economic activity. The sectoral approach was deployed having in mind that the next era of CSR should look out for a period of experimentation and innovation as organisations advance their core business objectives by addressing existing social and environmental issues, which are dependent on market and industry settings (Jose and Venkitachalam, 2019).

Next, the extracted sectors were evaluated based on their overall performance and potential for the Serbian economy. In order to better understand the sectoral approach to the current state of CSR towards children, in-depth interviews were conducted with a representative from one of the leading companies in the sector from the position CSR Manager. Of the ten requests for interviewing, five companies from the sectors of ICT, Food and Agriculture, Retail Trade, Media, and Banking participated in in-depth interviews conducted during March and April 2019.

Based on the conducted sectoral assessment, in the second phase of the research the mapped sectors were split into two tiers, wherein the first tier consists of three priority sectors that need to be engaged in the promotion of children's rights in Serbia. The priority sectors were finally evaluated based on:

- their direct and indirect impact on children's rights in the four key impact areas of CRBP; the workplace (key ways businesses can promote children's rights in the workplace), the marketplace (ensuring healthy, positive and appropriate products and marketing for children), the community (managing community impacts of operations, networks, products, and services) and the supply chain (ensuring children's rights are protected throughout a company's supply chain);

- the sectoral risk posed to children and communities (UNICEF, 2018b);

- the opportunities to engage in creating partnerships that have a SV for both children and business (UNICEF, 2018a).

For reciprocity, the data (DOI: 10.17632/yrx3z66pvr.1) used for the study has been uploaded on the Mendeley data repository, which can be retrieved from https://data.mendeley.com/datasets/yrx3z66pvr/1. 


\section{RESULTS AND DISCUSSIONS}

The results of the empirical research split the profile of the mapped sectors with strong impact on children and their rights into two tiers, as presented in Table 1. The first tier consists of the ICT, Food and Agriculture, and Banking and Insurance sectors, which are the three priority engagement sectors that need to be engaged in the promotion of children's rights in Serbia. The other tier, Tier 2, includes Pharmaceutical and Healthcare Equipment, Tourism, Textile, Retail Trade, Media, Sports, and Toys sectors, which can be selectively engaged in certain areas that cause children deprivation or bring about opportunities for enhancing children's rights.

Table 1 - Sector priority in shared value partnerships with organisations and institutions supporting children (source: empirical research by the authors)

\begin{tabular}{|l|l|}
\hline \multicolumn{1}{|c|}{ Tier 1 } & \multicolumn{1}{c|}{ Tier 2 } \\
\hline 1. ICT & 4. Pharmaceutical and Healthcare Equipment \\
2. Food and Agriculture & 5. Tourism \\
3. Banking and Insurance & 6. Textile \\
& 7. Retail Trade \\
& 8. Media \\
& 9. Sports and Toys \\
\hline
\end{tabular}

\section{ICT Sector}

With a strong engineering education background and outstanding skills, high fluency in English and attractive labour costs, Serbia is aiming to become an alternative to more traditional ICT markets, with the ICT sector ${ }^{1}$ becoming one of the key pillars of the Serbian economy (Deloitte, 2018). Given its strong results in attracting investors and employment, ICT is one of the healthiest sectors of the Serbian economy, and the priority sector for the Government in the forthcoming period (Kleibrink, et al., 2018). Cumulative ICT sector export revenues account for $19 \%$ of the total export of services (1.1 billion euros), where most revenues (89.2\%) were realised from the exports of information technology (IT) services, and 9.4\% from the export of telecommunications (Telco) services (Chamber of Commerce and Industry of Serbia, 2018). Serbia is also perceived as one of the most promising ICT outsourcing destinations in the world (Andjelković, Šapić and Skočajić, 2019). The IT sector consists of around 2,000 legal entities, it employs over 21,500 people ( $1.4 \%$ of the total workforce), records revenues of 1.8 billion euros and profits of 467 million euros, with an annual growth of $6 \%$ - which is steadily increasing (Vojvodina ICT Cluster 2018; CCIS, 2019b). In the structure of the sector, IT hardware is still considered to be the dominant segment (45\% share), followed by IT services $(37 \%)$, while the remaining $18 \%$ comes from software which, however, provided the bulk of the profits (60\%), and has the strongest export potential (Vojvodina ICT Cluster 2018; CCIS, 2019b). According to European standards, such a market structure indicates that the market is still not quite mature (Vojvodina ICT Cluster, 2018, p. 37).

1 The ICT sector is divided into two sub-sectors: telecommunications (Telco) and information technology (IT). Furthermore, the IT sub-sector comprises three segments: hardware, software, and IT-related services. 
From the perspective of local companies operating in the IT sector, foreign direct investments (FDIs) are seen more as a threat than a benefit due to the limited human resources available on the market. Namely, foreign companies tend to attract good IT experts by offering attractive salaries, which is something local companies cannot compete with (Vojvodina ICT Cluster, 2018, p. 26). However, the average salary in the IT sector is amongst the highest in the Serbian economy, especially in the field of computer programming, consultancy, and related activities (twice as high as the average) (Vojvodina ICT Cluster, 2018, p. 54).

Based on size, most IT companies are classified as micro companies (with an average number of employees close to six). Only eight IT companies have more than 250 employees, and small and medium enterprises (SMEs) account for $20 \%$ of all the IT companies. A huge number of micro companies $(1,629)$ with low financial capacities, insufficient technological, and management skills are also operational on the market (Vojvodina ICT Cluster, 2018, p. 49). The sector is also characterized by many freelancers, and informal commissioning is also common, with both methods of employment outside of official statistics (Kleibrink, et al., 2018). In 2017, a lot of effort and investments were made to build science, technology, and IT parks in Novi Sad, Niš and Indjija; however, private public partnerships (PPPs) are still an unused avenue for building more parks and IT-supporting infrastructures country-wide (Vojvodina ICT Cluster, 2018).

Based on the conducted in-depth interviews, we could conclude that the IT sector offers a familyfriendly workplace, aiming at branding the employees around corporate culture, and increasing their overall level of satisfaction. Some examples include remote and/or work from home, superficial office space with a cafeteria and a bar, interactive teambuilding with family members, a nursery within the business headquarters, private family healthcare, and the possibility of children spending a day at work with their parent. Most of the IT companies are not deeply rooted in the community, as they are either exporters or outsourcers. Lately, there has been an awakening of interest in employee volunteering and support to non-governmental organisations (NGOs) by deploying digital innovation and company expertise.

The more mature Telecom sector is dominated by three mobile operators and one cable operator. The sector operates through 250 companies, employing nearly 19,000 people (1.1\% of the total workforce), with revenues of 2.2 billion euros (driven from the provision of mobile services, $60 \%$ ) making a $4.5 \%$ contribution to the country's gross domestic product (GDP) (Vojvodina ICT Cluster, 2018; CCIS, 2019b). The value of investments in the Serbian Telecom sector in 2017 was over 250 million euros, which is close to the European average (300 million euros) (Vojvodina ICT Cluster, 2018, p. 43).

The Telco leaders at the Serbian market are very active and innovative in the CSR field, also dynamically supporting the business associations through which they promote and advocate on CSR. The areas of support include education on internet safety, raising awareness of digital violence, curbing the digital gender gap and the digital divide, enhancing digital competencies of children with disabilities, early childhood development programs, youth competitions in the field of core business (mobile applications), student internships, supporting work-life balance of young mothers, and donations in-kind to schools.

The assessment of the potential sectoral impact on children's rights in Serbia, perceived risks and opportunities for SVP with organisations, and institutions that support children and their rights are presented in Table 2: 
Table 2 - The potential impact of the ICT sector on children and opportunities for SVP (source: authors, based on Child Rights and the ICT Sector, UNICEF, 2018C)

\begin{tabular}{|c|c|}
\hline \multirow[t]{5}{*}{$\begin{array}{l}\text { Potential direct } \\
\text { and indirect } \\
\text { impact }\end{array}$} & $\begin{array}{l}\text { Marketplace (major impact area) } \\
\text { Ensure products and services promote and protect child rights in } \\
\text { use: Addressing violence, abuse and exploitation online, protecting } \\
\text { the privacy of young users' personal data, and preserving their right } \\
\text { to freedom of expression online. }\end{array}$ \\
\hline & Community \\
\hline & $\begin{array}{l}\text { Reinforcing government and community child rights initiatives: Gender } \\
\text { equality (uneven representation of women employed in the ICT industry } \\
\text { and enrolled at IT faculties); economic digital divide (vulnerable children } \\
\text { and poor families); territorial digital divide (discrepancy in internet con- } \\
\text { nection and presence of computers between Belgrade and Central Ser- } \\
\text { bia). Protect children affected by emergencies; e.g., by establishing the } \\
\text { internet and other means of electronic communication. }\end{array}$ \\
\hline & Supply Chain \\
\hline & Ensure workplace rights are upheld by suppliers and subcontractors. \\
\hline \multirow[t]{5}{*}{ Perceived risks } & $\begin{array}{l}\text { Children may be exposed to online exploitation or abuse if ICT com- } \\
\text { panies fail to create a safe and age-appropriate online environment. } \\
\text { Online safety for children has oriented around three primary areas: } \\
\text { - inappropriate content (disturbing or potentially harmful content); e.g., } \\
\text { images and descriptions associated with war and other atrocities, do- } \\
\text { mestic abuse and violence, cruelty to animals, and harmful material } \\
\text { that may promote racial and religious hatred, homophobia, or mi- } \\
\text { sogyny. Children may also be exposed to content that discusses suicide, } \\
\text { self-harm, and eating disorders. Inappropriate content may also include } \\
\text { a reference to child sexual abuse images and videos. } \\
\text { - inappropriate contact (online grooming) }\end{array}$ \\
\hline & $\begin{array}{l}\text { - inappropriate conduct (cyberbullying), e.g., spreading rumours; } \\
\text { posting false information or nasty messages, embarrassing com- } \\
\text { ments or photos; or excluding someone from online networks or } \\
\text { other forms of online communications. }\end{array}$ \\
\hline & $\begin{array}{l}\text { Missed opportunity to design child safety features / protection of } \\
\text { child rights into products. }\end{array}$ \\
\hline & Compromising young users' personal data. \\
\hline & Electronic waste leading to hazards in collection and processing. \\
\hline \multirow{3}{*}{$\begin{array}{l}\text { Opportunities } \\
\text { for SVP }\end{array}$} & Advocacy \\
\hline & Awareness raising: Online violence against children/Safe use of the internet \\
\hline & $\begin{array}{l}\text { Influencing policy sector and government agenda: Addressing the is- } \\
\text { sue of the Digital divide; fostering enrolment at STEM faculties with } \\
\text { increased quotas. } \\
\text { Agenda setting through platforms (Digital Serbia, cluster ICT initiatives): } \\
\text { advancement of digital literacy; Gender equality/Women in Tech. }\end{array}$ \\
\hline
\end{tabular}




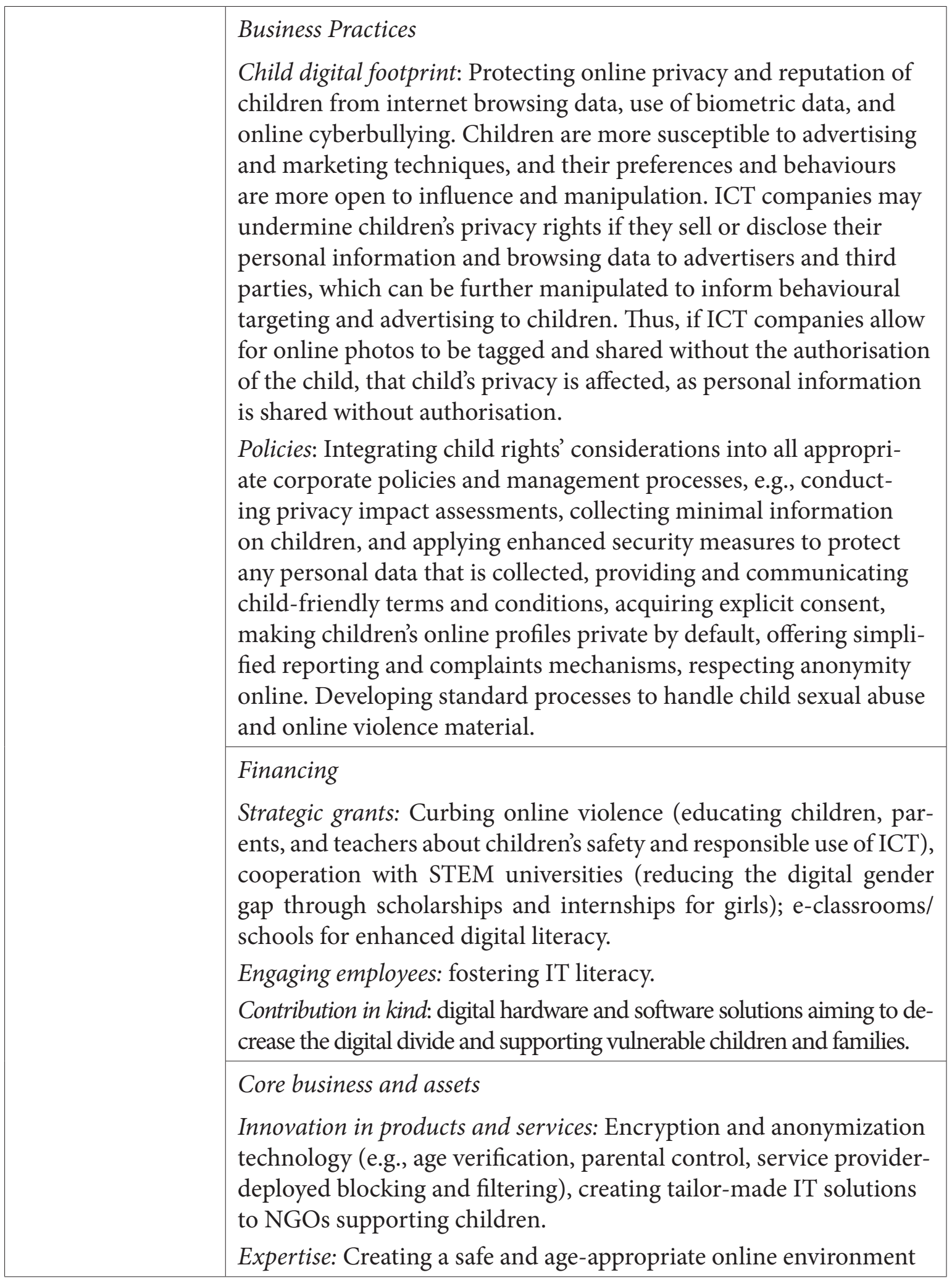




\section{Food and Agriculture}

Agriculture in Serbia has strong growth potential, and is the main engine behind the development of rural areas (Ministry of Agriculture - MoA, 2012). Serbia is blessed with very favourable natural conditions (land and climate) for agricultural production since it has one of the cleanest soils in Europe with over 6 million hectares of agricultural land, $60 \%$ of which is arable, and around $90 \%$ is in private ownership (Development Agency of Serbia - RAS, 2017, p. 3). As for the agricultural production structure, crop field production (mostly cereal crop production: wheat, barley, rye, oats, corn, millet and sorghum) makes up two-thirds of the structure, while livestock production makes up one-third (MoA, 2012, p. 2). Serbia also ranks as one of the world's largest producers of plums and raspberries. Other important agricultural products are sunflower, sugar beet, barley, soybean, potato, apple, pork and chicken meat, beef, poultry, and dairy (MoA, 2012, p. 2). As an important indicator of Serbia's efforts to produce good-quality and healthy food, Serbian law prohibits the production and import of any genetically modified foods and seeds (GMO) (Deloitte, 2018). Serbia also plans to allocate 20\% of its agricultural land to be converted for organic production over the next ten years (RAS, 2017).

In 2017, the agriculture sector ${ }^{2}$ accounted for $6 \%$ of the Serbian GDP, attracted $11.1 \%$ of the country FDIs, with a recorded 2.7 billion euros of exports, thus becoming one of the few industry sectors to record a trade surplus (World Bank, 2018). Serbia is the biggest exporter of food among the Central European Free Trade Agreement (CEFTA) countries, and the only net exporter. The most important export products are fresh and frozen fruits (raspberries, apples, plums, cherries), maize, wheat, beet or cane sugar, vegetables, non-alcoholic beverages and beer made from malt (World Bank, 2018). Employment in agriculture in Serbia (as a percentage of total employment) was reported at $19 \%$ in 2017 (World Bank, 2018), whilst the average net salaries in the sector are about 15\% lower than the Serbian average, with the informal sector making up a large part of employment (MoA, 2017). Although Serbia is among the top ten European net exporters of agricultural and food products, much of its potential remains untapped. The challenges are that the average yields per hectare are lower than the EU average, the assortment of products is relatively low-value, there is low productivity due to outdated technologies and infrastructure, as well as small economic size and low utilisation of agricultural land per farm (European Commission, 2018, p. 13). Significant challenge comes also from internal migration trends; because of the lower standard of living in rural areas, young people are increasingly leaving the countryside for big cities (European Commission, 2018, p. 13).

From the interview with one of the leading companies from the sector, we could conclude that the sectoral CSR activities are based on target groups (e.g., the youth for soft drinks, and children for dairy producers), as they often make up part of the parent group's global projects, or are the result of a domestic owner's philanthropic beliefs. Some of the projects focus on encouraging small farmers to remain on their farms and improve their sustainability through the supply chain. Additionally, a decrease in the operations' environmental impact, educating children on food labelling, donations in-kind, and youth mentorship and internship projects are also in the focus of CSR activities.

The assessment of the potential impact of the food and agriculture sector on children's rights in Serbia, perceived risks and opportunities for SVP with organisations and institutions that support children and their rights is presented in Table 3:

2 Under the Food and Agriculture sector, the agricultural production, hunting, and accompanying service activities and production of food products were analysed. 
Table 3 - The potential impact of the food and agriculture sector on children and opportunities for SVP (source: authors, based on UNICEF Children's Rights and Business Atlas)

\begin{tabular}{|c|c|}
\hline \multirow[t]{10}{*}{$\begin{array}{l}\text { Potential direct } \\
\text { and indirect } \\
\text { impact }\end{array}$} & $\begin{array}{l}\text { Workplace } \\
\text { Inadequate employment protection for parents and caregivers. } \\
\text { Respecting the rights of young workers and encouraging their education. } \\
\text { Children may be pushed into child labour as a result of poverty. }\end{array}$ \\
\hline & Marketplace (major impact area) \\
\hline & High-sugar and calorie-dense food. \\
\hline & $\begin{array}{l}\text { The negative contribution of child-directed marketing and advertising of } \\
\text { food with a high content of fat, sugar and salt on overweight and obesity } \\
\text { rates in children. }\end{array}$ \\
\hline & Community \\
\hline & $\begin{array}{l}\text { Exposing children to harmful chemicals or contaminated local water } \\
\text { supplies. }\end{array}$ \\
\hline & $\begin{array}{l}\text { Environmental degradation may disrupt agricultural production and } \\
\text { undermine the livelihoods of local communities. }\end{array}$ \\
\hline & Supply chain \\
\hline & Ensure workplace rights are upheld by suppliers and subcontractors. \\
\hline & $\begin{array}{l}\text { Ensure suppliers' products are safe and meet international health and } \\
\text { safety standards. }\end{array}$ \\
\hline \multirow[t]{3}{*}{ Perceived risks } & Young workers are increasingly leaving the countryside for big cities. \\
\hline & $\begin{array}{l}\text { Although most companies have Codes of Conduct when it comes to } \\
\text { child labour, the risk of child labour in the agriculture supply chains } \\
\text { still exists, because of root causes, including poverty and limited ac- } \\
\text { cess to education. Lack of knowledge by suppliers on how to identify } \\
\text { / mitigate child rights impacts/risks. }\end{array}$ \\
\hline & $\begin{array}{l}\text { Working conditions: decent wages, maternity/paternity protection, } \\
\text { big part of the employment comes from the informal sector. }\end{array}$ \\
\hline \multirow[t]{6}{*}{$\begin{array}{l}\text { Opportunities } \\
\text { for SVP }\end{array}$} & $\begin{array}{l}\text { Lack of adequate nutritional information, limiting children, parents } \\
\text { and caregivers from making informed or healthy food choices. }\end{array}$ \\
\hline & $\begin{array}{l}\text { Advertising that promotes an unhealthy diet could increase the risk of } \\
\text { overweightness, and obesity among children. }\end{array}$ \\
\hline & $\begin{array}{l}\text { Unregulated agricultural practices, such as cutting down forests, hay } \\
\text { burning, partitioning and polluting rivers can have serious impacts } \\
\text { on local communities. }\end{array}$ \\
\hline & Advocacy \\
\hline & $\begin{array}{l}\text { Awareness raising on healthy food/nutrition and the importance of } \\
\text { sports in children. }\end{array}$ \\
\hline & $\begin{array}{l}\text { Agenda setting through platforms (International Advertising Associa- } \\
\text { tion, IAA, International Advertising Bureau, IAB): Responsible mar- } \\
\text { keting, advertising, labelling. }\end{array}$ \\
\hline
\end{tabular}




\begin{tabular}{|l|l|}
\hline $\begin{array}{l}\text { Business practice } \\
\text { Policies: Build children's rights into selection, review, and training } \\
\text { of suppliers; Code of responsible advertising, International Code of } \\
\text { Marketing of Breast-milk Substitutes; Review of current labelling pro- } \\
\text { cedures for food and beverage targeting children and adolescents. }\end{array}$ \\
$\begin{array}{l}\text { Financing } \\
\text { Strategic grants: Programs promoting healthy lifestyles; Agricultural } \\
\text { education, e.g., introduction of new biotechnologies and modern } \\
\text { ways of farming in high-school and university curriculums, support } \\
\text { to agricultural and veterinary schools, faculties and institutes, grant- } \\
\text { ing scholarships to young farmers. } \\
\text { Engaging customers: donating money in cooperation with customers } \\
\text { for child-related social goals. } \\
\text { Contributions in-kind (food): vulnerable and children affected by } \\
\text { emergencies. }\end{array}$ \\
$\begin{array}{l}\text { Core business and assets } \\
\text { Innovation in products: enhanced ecological principles in soil usage to } \\
\text { decrease the community environmental impact in agri-business. } \\
\text { Expertise: sharing global/regional know-how with the supply chain to } \\
\text { enhance their capacities. }\end{array}$ \\
\hline
\end{tabular}

\section{Banking and Insurance}

The Serbian banking sector consists of 29 banks, dominated by foreign-owned banks ( $71 \%$ of the market share) mainly from Italy, Austria, France and Greece. The network is comprised of 1,633 business units and employs over 23,000 persons with a decreasing trend, mainly due to digitalization (National Bank of Serbia, 2018, p. 3-4) and with earnings significantly higher than the average (CCIS, 2019a). In terms of net profits, 24 banks operate with a surplus, whilst five banks (with a market share of 1\%) posted a negative financial result (National Bank of Serbia, 2018, p. 6). The sector is characterised by an acceptable level of competition and low concentration of activities, with the highest values in deposits (chiefly household deposits) and income from fees and commissions, and the lowest figures for total gross loans to corporates (National Bank of Serbia, 2018, p. 4). Thus, the sector is highly liquid and well-capitalised (European Commission, 2018, p. 6), but also highly euroized, even though during the last two years the overall deposit and loan dinarisation increased (Deloitte, 2018). Some holders of mortgage loans indexed in Swiss Francs have had their homes seized because they were unable to meet payments when the exchange rate changed, and the Government has engaged itself in finding a sustainable solution for them. Some progress has been seen in implementing the Non-performing loans (NPL) Resolution Strategy of the Serbian Government (European Commission, 2018, p. 19), as it contributed to lowering the gross NPL, although the major part of NPLs is still in the corporate segment making banks resilient to lend (NBS, 2018, p. 17). The top five banks (in terms of balance-sheet assets, gross loans and deposits) account for more than half of Serbia's banking sector (NBS, 2018, p. 3). 
The insurance market in Serbia shows a moderate level of concentration, comprising 21 insurance undertakings (four life insurers, seven non-life insurers and six both life and non-life insurance), 16 of which are in foreign ownership, whilst employment in the sector accounts for over 10,000 persons, with decreasing trends (NBS, 2018, p. 4). In terms of premium, the share of non-life insurance makes up two-thirds of the market (78\%) and life insurance one fifth (22\%) (NBS, 2018, p. 4).

From the interview with the leading sectoral market player, it was concluded that of all the sectors, banks were among the first entering the field of CSR, and are very active in business associations and platforms through which corporate responsibility is advocated. In the past, banks mostly supported largescale programs targeting children and the community; e.g., the refurbishment of parks, playgrounds, affinity payment cards supporting a cause, helping vulnerable and children with disabilities, culture, sports, environmental protection and donations to children hospitals. Recently, a shift has been made towards sustainability reporting, measuring the socio-economic impacts of operations, and employee engagement (volunteerism, mentoring). Due to strong digitalisation trends, some banks have embarked on digital innovations, supporting youth and student hackathons, and establishing partnerships with ICT and creative hubs. Improving the financial literacy of children and youth by teaching them how to save money is also in the spotlight, where banks either launch their own program, or collaborate with the Association of Serbian Banks (ASB). Finally, insurance companies are active in promoting healthy lifestyles in children through sports, or are occasional philanthropists for children's institutions and organisations.

The assessment of the potential impact of the banking and insurance sector on children's rights in Serbia, as well as the perceived risks and opportunities for SVP with organisations and institutions that support children and their rights is presented in Table 4.

Table 4 - The potential impact of the banking and finance sector on children and opportunities to engage in SVP (source: authors, based on UNICEF and CYFI, 2013)

Potential direct
and indirect
impact

Workplace

Respecting the rights of young workers with decent wages and enabling them to continue their education.

Marketplace (major impact area)

Availability and accessibility of financial services to certain categories of young people (e.g., freelancers, start up's, youth entrepreneurs, students).

Technology is driving a shift in payments from cash to electronic forms, and young people without access can be socially and financially excluded. Youth may be forced to delay life-cycle milestones (moving out of the parental home, getting a first apartment) due to unfavourable economic conditions, which requires financial institutions to adapt their lending criteria, delinquency aging, and collections practices.

Indirect impacts on children and families in investment decisions through indebtedness and financial exclusion.

Community

Financial literacy of children and youth.

Financing of PPP projects in the segment of healthcare, education, and social services.

Supply chain

Respecting children's rights in outsourced security arrangements at branches. 


\begin{tabular}{|c|c|}
\hline \multirow[t]{3}{*}{ Perceived risks } & $\begin{array}{l}\text { Security risks for children from phishing attempts, fraudulent } \\
\text { email, cyber-attacks and identity thefts. }\end{array}$ \\
\hline & Indebtedness and financial exclusion of youth and families. \\
\hline & $\begin{array}{l}\text { Responsible marketing and advertising, e.g., content that promotes } \\
\text { positive financial behaviour; not hiring children to promote adult } \\
\text { services (e.g., cash, mortgage loans, travel insurance), or using car- } \\
\text { toons as 'brand ambassadors. } \\
\text { Targeting young people for credit cards with a consequential rise in } \\
\text { over-indebtedness. }\end{array}$ \\
\hline \multirow[t]{7}{*}{$\begin{array}{l}\text { Opportunities } \\
\text { for SVP }\end{array}$} & $\begin{array}{l}\text { Advocacy } \\
\text { Awareness raising on risks of sharing personal details online. } \\
\text { Agenda setting through platforms (ASB): Access to finance for youth } \\
\text { entrepreneurs and digital freelance workers without creditworthiness. }\end{array}$ \\
\hline & $\begin{array}{l}\text { Business practice } \\
\text { Policy commitment to respect and support children's rights: Proce- } \\
\text { dures for safeguarding child rights in security arrangements; Risk } \\
\text { assessment on children's rights in financing; Assessing the impacts of } \\
\text { child-friendly products and services (in product design, access and } \\
\text { delivery options, child- and youth-friendly communication strate- } \\
\text { gies, the inclusion of financial education components). }\end{array}$ \\
\hline & $\begin{array}{l}\text { Financing } \\
\text { Strategic grants: Support youth through projects aimed towards } \\
\text { skills-building, promotion of youth entrepreneurship. }\end{array}$ \\
\hline & $\begin{array}{l}\text { Engaging customers: Co-branded payment cards for child-related causes. } \\
\text { Engaging employees: Volunteering, mentorship to schools and faculties } \\
\text { (building financial capacity, literacy, and entrepreneurship culture). }\end{array}$ \\
\hline & $\begin{array}{l}\text { Contribution in-kind: Direct debit for child-related donations and } \\
\text { current accounts lifted from fees }\end{array}$ \\
\hline & $\begin{array}{l}\text { Core business \& assets } \\
\text { Innovative services: Access to finance for youth entrepreneurs and } \\
\text { digital freelance workers; Building a child rights approach into } \\
\text { design options for services (deposit options, mobile and internet } \\
\text { banking access, control, and security features); University affinity } \\
\text { card programmes. }\end{array}$ \\
\hline & $\begin{array}{l}\text { Expertise: Strengthening youth entrepreneurship and financial lit- } \\
\text { eracy (building financial capability and literacy, promoting financial } \\
\text { education and a positive financial culture). }\end{array}$ \\
\hline
\end{tabular}




\section{CONCLUSION}

The paper makes several contributions to CSR management studies. First, it provides theoretical and empirical insights into the business sector's impact on children's rights in Serbia, which is still a relatively unclear, ungoverned, and underresearched topic. The results suggest that children as a group of stakeholders need special consideration. They represent around one fifth of the total population in Serbia, and are among the most sensitive and vulnerable societal groups, impacted both directly and indirectly by the business sector, at the workplace, in the marketplace, in the community, and through the supply chain, where risks arise in terms of endangering children's rights.

Second, the research confirms theoretical results which suggest that no national strategy or processes of certification on CSR activities cover the area of children's rights based on internationally acclaimed CRBP. Research conducted in this field clearly concludes that the business sector highly values activities toward children and frequently engages in these kinds of activities, yet children's rights remain unregulated and unmeasured in business strategies, policies, and politics (UNICEF, 2018).

Third, the conducted research expands existing academic research on creating SV for businesses by extending the concept of CSR, as long-term competitiveness and sustainability of companies depend on social conditions where children's rights are of great importance. Accordingly, the impact of the business sector on children and their rights should be diverted from one-off donations and philanthropy to the exploration of opportunities and mechanisms for creating SV's with organizations and institutions that support children's rights in society. In this process, it is necessary to begin identifying the areas of influence and related risks, which should create inspiration for areas of action in which it is possible to create shared values.

Results suggest that the major impact area for all three examined business sectors - ICT, food and agriculture, and the financial sector - is the marketplace. It ensures that products and services are safe for children and seeks to support children's rights through them, which it does through using marketing and advertising that respect and supports children and their rights. The mapped key impact area creates related risks, which are also associated with the use and availability of products and services, their responsible promotion, and the environmental risks posed to the local community. The opportunities for SVP for all three sectors can be found in advocacy initiatives on raising awareness on the perceived risks that children could be exposed to using companies' products and services, and agenda setting through influential sectoral platforms. Furthermore, child rights consideration should be integrated into all appropriate corporate procedures and committed by management processes. Financing should be covered from a broader angle, from strategic grants and contributions in-kind to employee engagement in terms of their time and expertise, and customers around the cause of the support and promotion of children's rights in Serbia. Finally, a clear untapped potential can be found in innovative products and services and the expertise of the leading companies in the sector, which would make their offer more inclusive and impact the overall wellbeing of children, thereby creating a business contribution to the Sustainable Development Goals.

With this paper, the authors hope to inspire further research focused on initiatives the business sector participants could implement based on mapped opportunities in terms of SV creation, and quantifying this value for children in society. The development of company studies and sectoral cases to illustrate the benefits to children as important stakeholders in society, and to look at the process of creating shared value would provide significant stimulus for the business community to follow good examples using an experienced and tested approach recognised at the sectoral level. 


\section{ACKNOWLEDGEMENTS:}

The research for this article was conducted within the project "Situation Analysis on Children in Serbia" for the United Nations Children's Fund during the period of March-April, 2019.

\section{REFERENCES}

Anđelković, B., Šapić, J. and Skočajić, M. (2019, February). Gig economies in Serbia: who are digital workers and workers from Serbia and why are they working on global platforms? (Gig ekonomija u Srbiji: ko su digitalni radnici i radnice iz Srbije i zašto rade na globalnim platformama?). Belgrade: Center for Policy Research/

Berlan, A. (2016). Whose Business is it Anyway: Children and Corporate Social Responsibility in the International Business Agenda. Children \& Society, 30(2), 159-168. https://doi.org/10.1111/chso.12149.

Carlson, L. and Clarke, B. (2014). Reassessing the Current State of Advertising to Children. International Journal of Advertising, 33(3), 429-436. https://doi.org/10.2501/IJA-33-3-429-436.

Chamber of Commerce and Industry of Serbia. (2019a). e-Newsletter: Association for banking, insurance and other financial institutions, I quarter 2019. Belgrade: CCIS.

Chamber of Commerce and Industry of Serbia. (2019b). e-Newsletter: Association for the electronic communications and information society', III quarter 2018. Belgrade: CCIS.

Collins, T. M. (2014). The relationship between children's rights and business. International Journal of Human Rights, 18(6), 582-633. https://doi.org/10.1080/13642987.2014.944805

Crane, A. and Kazmi, B. A. (2010). Business and Children: Mapping Impacts, Managing Responsibilities. Journal of Business Ethics, 91(4), 567-586. https://doi.org/10.1007/s10551-009-0132-y.

CSR Europe. (2016). Blueprint For Embedding Human Rights in Key Company Functions, Brussels: Belgium. Retrieved July 5, 2019 from https://www.csreurope.org/sites/default/files/uploads/Human_Rights_Blueprint.pdf.

Deloitte. (2018, April). Guide for investing in Serbia: At your glance. Retrieved June 12, 2019, from https://www2. deloitte.com/content/dam/Deloitte/rs/Documents/about-deloitte/Investing_in_Serbia_May\%202018.pdf

Development Agency of Serbia. (2017, February). Serbia food industry. Belgrade: RAS.

European Commission. (2018, April 17). Economic reform programme of Serbia (2018-2020) - Commission assessment. Brussels: Commission staff working document SWD (2018) 132 final, p.14.

Filho, W.L, Idowu, S.O. and Louche, C. (2010). Innovative CSR: From Risk Management to Value Creation. Sheffield, UK: Routledge.

Gerber, P., Kyriakakis, J. and O'Byrnet, K. (2013). General Comment 16 on State Obligations Regarding the Impact of the Business Sector on Children's Rights: What Is Its Standing, Meaning and Effect? Melbourne Journal of International Law, (1), 93-128.

Jose, S. and Venkitachalam, K. (2019). A matrix model towards CSR - moving from one size fit approach. Journal of Strategy and Management, 12(2), 243-255. https://doi.org/10.1108/JSMA-07-2018-0071.

Kleibrink, A., Radovanovic, N., Kroll, H., Horvat, D., Kutlaca, D. and Zivkovic, L. (2018). The Potential of ICT in Serbia: An Emerging Industry in the European Context. Luxemburg: Publications Office of the European Union. ISBN 978-92-79-98369-6, doi:10.2760/994464, JRC114209.

Krstić, N. (2017). The implementation of Children's Rights and Business Principles in the corporate social responsibility strategy of Serbian enterprises. Sociology, 59(3), 351-363. https://doi.org/10.2298/SOC1703351K.

Lahtinen, S. Kuusela, H. and Yrjölä, M. (2018). The company in society: when corporate responsibility transforms strategy. Journal of Business Strategy, (4), 11-18. https://doi.org/10.1108/JBS-05-2017-0069

Ministry of Agriculture, Trade, Forestry and Water Management. (2017, June). Competitiveness of Serbian agriculture. Belgrade: Seedev.

Ministry of Agriculture, Trade, Forestry and Water Management. (2012). Serbia agriculture: fact sheet 2012. Belgrade: Deutsche Gesellschaft für Internationale Zusammenarbeit GIZ. 
National Bank of Serbia. (2018, September). Banking sector in Serbia: First quarter report 2018. Belgrade: Bank Supervision Department. Retrieved April 4, 2019, from https://www.nbs.rs/internet/english/55/55_4/ quarter_report_I_18.pdf.

National Bank of Serbia. (2018). Insurance sector in Serbia: Second Quarter Report 2018. Belgrade: Insurance Supervision Department. Retrieved April 4, 2019, from https://www.nbs.rs/internet/english/60/60_6/ insurance_II_2018.pdf.

Obara, L. J. and Peattie, K. (2019). Bridging the great divide? Making sense of the human rights-CSR relationship in UK multinational companies. Journal of World Business, 53(6), 781-793. https://doi.org/10.1016/j.jwb.2017.10.002.

Office of the High Commission for Human Rights. (2011). Guiding Principles on Business and Human Rights: Implementing the United Nations "Protect, Respect and Remedy" Framework, New York \& Geneva: United Nations. Retrieved May 17, 2019, from www.ohchr.org/EN/PublicationsResources/Pages/ReferenceMaterial.aspx.

Paine, L.S. and Srinivasan, S. (2019). A Guide to the Big Ideas and Debates in Corporate Governance. Harvard Business Review, October 14. Retrieved October 25, 2019 from https://hbr.org/2019/10/a-guide-to-thebig-ideas-and-debates-in-corporate-governance

Porter, E. M. and Kramer, R, M. (2011). Creating Shared Value. How to reinvent capitalism-and unleash a wave of innovation and growth. Harvard Business Review, January - February 2011. Retrieved May 4, 2019 from http:// www.coherence360.com/praxis/wp-content/uploads/2015/08/Michael_Porter_Creating_Shared_Value.pdf.

Remmert, G., Koalick, M. and Mahler, C. (2013). Respecting Human Rights - An Introductory Guide for Business, Global Compact Network, twentyfifty Ltd. \& German Institute for Human Rights. Retrieved July 5, 2019 from https://www.globalcompact.de/wAssets/docs/Menschenrechte/Publikationen/respecting_human_rights-an_introductory_guide_for_business.pdf

Sinha, M. K. (2013). Business and Human Rights. New Delhi: Sage Publications Pvt. Ltd.

Smaiziené, I. (2015). Children-Engaging Social and Environmental Initiatives as Determinants of Corporate Reputation. Entrepreneurial Business and Economics Review, 3(4), 89-103, DOI: 10.15678/EBER.2015.030406.

Statistical Office of the Republic of Serbia (2018, December). Poverty and Social Inequality, 2017. Retrieved July 8, 2019, from http://www.stat.gov.rs/en-us/vesti/20181225-siromastvo-i-socijalna-nejednakost-2017/?s=0102.

The World Bank. (2018, September). Employment in agriculture (\% of total employment) (modelled ILO estimate). International Labour Organization, ILOSTAT database. Retrieved April 11, 2019, from https:// data.worldbank.org/indicator/SL.AGR.EMPL.ZS

United Nations Children Fund. (2018a). Prospecting companies for UNICEF Priority Shared Value Partnerships (PSVPs) - a bit of history. New York: UNICEF.

United Nations Children Fund. (2018b, May). Child Safeguarding Toolkit for Business. Geneva: UNICEF’s Child Rights and Business Unit.

United Nations Children Fund. (2018c). Child Rights and the ICT Sector. Retrieved April 17, 2019, from https:// www.unicef.org/csr/files/Training_Module_1_Child_Rights_and_the_ICT_Sector.pdf.

United Nations Children Fund. (2018d). Privacy, protection of personal information and reputation rights. Discussion paper series: Children's Rights and Business in a Digital World. Geneva: UNICEF Child Rights \& Business Unit.

United Nations Children's Fund. (2018e, May). A third research by UNICEF on the implementation of Children's Rights and Business Principles in Serbia, Retrieved June 17, 2019, from https://www.unicef.org/serbia/ medija-centar/vesti/trece-istrazivanje-o-primeni-principa-poslovanja.

United Nations Children's Fund and Child and Youth Finance International - CYFI. (2013, May). Beyond the promotional piggybank: Towards children as stakeholders. Retrieved April 7, 2019, from https://www. unicef.org/csr/css/UNICEF-CYFI_Beyond_the_Promotional_Piggy_Bank_06_05_13.pdf.

United Nations Children's Fund and Danish Institute for Human Rights (2013). Children's Rights in Impact Assessments: A guide for integrating children's rights into impact assessments and taking action for children. Geneva. UNICEF. 
United Nations Children Fund and Global Child Forum. Children's Rights and Business Atlas. Retrieved April 2, 2019, from https://www.childrensrightsatlas.org/.

United Nations Children Fund, The Global Compact and Save the Children. (2012). Children's Rights and Business Principles. Retrieved March 17, 2019, from http://childrenandbusiness.org/.

Vojvodina ICT Cluster. (2018). ICT in Serbia: At a Glance 2018. Novi Sad: Vojvodina ICT Cluster. Retrieved April 5, 2019, from https://vojvodinaictcluster.org/wp-content/uploads/2018/05/ICT-in-Serbia-\%E2\%80\%93-At-a-Glance-2018.pdf. 


\section{UTICAJ POSLOVNOG SEKTORA NA PRAVA DECE U SRBIJI}

\section{Rezime:}

Poslovni sektor vrši jak direktan i indirektan uticaj na decu, na radnom mestu, tržištu, u zajednici i preko lanca snabdevanja, gde se pojavljuju rizici u smislu ugrožavanja dece i njihovih prava. Ovaj članak ima za cilj da pruži nove dokaze o uticaju poslovnog sektora na dečja prava u Srbiji. Analiza uticaja poslovnog sektora u Srbiji na prava dece sprovedena je putem kabinetskog istraživanja tri sektora koja su identifikovana kao prioritetna u pogledu njihovog uticaja na ekonomiju i prava dece - IKT, hrana i poljoprivreda, i finansijski sektor. Nakon intervjua sa rukovodiocima za društveno odgovorno poslovanje u vodećim preduzećima iz ovih sektora, mapiran je njihov potencijalni uticaj na prava dece zajedno sa sektorskim rizicima, i prikazane su prilike za angažovanjem u stvaranju zajedničkih vrednosti između preduzeća i organizacija i institucija koje podržavaju decu i njihova prava. Naše istraživanje sugeriše da zajednička vrednost u kontekstu promocije prava dece prevazilazi tradicionalnu korporativnu filantropiju i ukazuje kako osnovna poslovna delatnost, imovina i prakse, inicijative zagovaranja, veštine i stručnost mogu podržati prava dece radi postizanja Ciljeva održivog razvoja.

\section{Ključne reči:}

principi poslovanja i prava dece, društveno odgovorno poslovanje, zajednička vrednost, Srbija. 